\title{
Of People and Protest: Spiritual Resistance in Newar Hymns
}

\author{
--Komal Prasad Phuyal \\ Assistant Professor, \\ Central Department of English, \\ Tribhuvan University, Kathmandu, Nepal. \\ Email: ephuyal@gmail.com
}

https://doi.org/10.3126/litstud.v34i01.39527

\section{Abstract}

The spiritual and the political at times merge together in the formation of powerful voice of protest in quest of social harmony. This is also seen in Newari cultural landscape. Newari hymns present that the collective imagination poetically transcends beyond the earthly domain of control of authority and social structures, revolting against the prevalent social order. The paper studies two historical Newari hymns "Shitala Maju" and "Bijaya Laxmi" from the perspective of the cultural resistance. When the hymns that are still sung as integral cultural performance in social life of the Newari settlements are analysed to examine the nature of their spiritual quest, the hymns, in the form of devotional poetry, emerge as a sharp critique of the then power structure. This paper argues that the Newari hymns raise the voice of people against the atrocities of both the state and/or the King in the form of spiritual resistance in its inner core though such poems externally display devotion as their primary ethos.

Keywords: Spirituality, Resistance, Newari Hymns, Cultural Performance, Devotion

Culturally unique people of the Kathmandu Valley, the Newars possess and perform devotional poetry and music which capture the tension between the person and the polity in the most telling way. In spite of devotion as the key dynamics in their appearance, such hymns project protest of the people at the bottom of society as voice of spiritual resistance. The social mores and orders of/from the authority mostly act coercively on the self of people who find themselves pushed away at the margin of the society. The social set up functions as another major force to suppress the call for protest in general. For instance, "Shitala Maju" offers prayers to the Goddess Shitala against the atrocity of the King Rana Bahadur Shah who had issued decree to expel all the children infected with small pox from the Valley. The King intended to protect his son Girvana by driving away all infected people in the 
epidemic from the Valley. When the office of the public safety centers on the fulfilment of the personal gains and realization of personal goals of the people at the power, the division between the worldly and the heavenly is blurred even in the devotional ways of the people. Despite their devotional outlook, the hymns sharply critique the political ways of the time. Similarly, the King's Sati, Bijaya Laxmi stands as the most humane form of the time in the hymn, while all the rulers and the courtiers enforce the practice of traditional mode of cremation upon the living queen. The voice of protest is embedded in the hymns as the Sati wants to hug her son and feel the warmth of the earth before sitting in the pyre. The unspeakable pain and suffering of the people during the journey turn into the subject matter for the invocation of the Devi in the external form, while the deep-seated revolt of the people is expressed through the depiction of the grievous journey forced upon the innocent subjects. The people do not accept the dictations of the authority: they employ spirituality as a form of resistance to voice protest.

Spirituality is often viewed in terms of devotion and inner awakening for the inner soul that is supposed to have a very apolitical connotation in the analysis of social structures. Generally, it refers to the individual practice of actualizing self in a private zone, away from collective life possible in regular mode of social configuration. Indeed, the ahistorical appearance of spirituality supports its apolitical appearance. However, the people in their politicomental landscape exercise spirituality as a tool of resistance in which they project and perceive a higher order of power through imagination. As a part of quest for meaning in life, people invent powerful narratives, sing them in praise of the divine power, and thus derive new meaning for their self and society. The rewriting of the social challenges occurs as the conscious choice of the people at the collective level. In past, the popular ballads have appeared as one of the fundamental sites of resistance as such in that such popular form of music critiques the contemporary social reality through the praise of the divine. In this sense, the hymns merge both the worldly and the divine in quest of justice where human agency is celebrated as the key point of departure in that human beings make and remake such narratives to add meaning in their social milieu. Kasper Masse emphasizes on contents when he argues, "What forms of expression and behaviour count as resistant in a society ... is primarily a result of reciprocal perception, and the object of practical negotiation. No cultural form is resistant or challenges established power structures on its own, independent of any context" (46). Even the spiritual forms of cultural productions hold high degree of potential of carrying political undertones in a culturally different context, for the historical and social forces posit a new lens for circulation and interpretation of new 
meaning in culturally vibrant texts. A very ahistorical reading of hymns reveals only the devotional dimension and praise for the divine only, while the analysis based on context and other historical factors links the socially significant aspects of the any spiritual and/or socio-political phenomena to reveal the power relationships from the perspective of the oppressed and the downtrodden.

Spiritual quest in the Newar settlements in the Valley has always fascinated critical scholarship to examine the way of life, generation of meaning, and cultural performances. For example, Steven M. Parish and Bruce McCoy have studied the formation of Newar self through scrutiny of moral consciousness and interaction of the divine and the human in Newar culture. For Parish, the Newar people assume they are endowed with certain capability to understand their own situation. He argues, "by viewing people as endowed with bibek, a cognitive power, and as having a moral god immanent in the heart, Newars see people as capable of moral knowing in a broad sense" (323) . The formation of their consciousness reveals the higher order of control in their mindset results from their sense of justice. The inner coherent and ideal world stands as the mast in their individual and collective life. On the other hand, the divine-human interaction emerges as one of the basic aspects of such formation of Newar self in general. Bruce McCoy Owen has identified that the people have shown their role in inventing and determining the divine in their location. Since human agency surfaces as a major issue in such kind of initiation of religious acts, the Newars in the Valley have a very humanistic approach to life and society (210). As anthropological study of the formation of Newar self, both Parish and Owen interrogate the inner content of Newar organization of mental landscape. Both focus on the static picture of the being of the people in their cultural and spatial position.

The ritual performances and oral ways of life have also added to the social organization of the Kathmandu Valley. The text seeks the company of people and musical instruments, while the oral tradition turns into a backdrop for such performances to reward the social life with new perspectives and meanings. The traditional ways of musical performance form a huge cultural aspect of the Newar society. For example, Richard Widdess has studied the ways in which text, oral tradition, and performance are brought together in the Newar settlements. He states that the Newars of the Valley perform dapha after as part of ritual performance where the devotional music becomes a way of reorganizing the spiritual strength of the people (237). Dapha celebrates the collective communal emotional bond in the people. In Newar culture, the evening singings provide with one of such spaces where the political tension transcends the regular state affairs in search of the ideal reality, for the people 
believe that the ideal helps prevail the coherence in the social life. Despite such serious studies on the Newar self, performance, and society, the critical scholarship has not been able to delve into the spiritual forms of resistance that the ballads from the past have possessed in them. As the paper builds its argument on the foundation that both the spiritual and the political intertwine as the fine fibers of social interweaving, the close analysis of two hymns, "Shitala Maju" and "Bijaya Laxmi" along with their contexts reveal the ways in which the Newars of the Valley have made use of spirituality as a political form and instrument of resistance.

The Newars of the Kathmandu Valley still sing these two hymns as part of their ritual performance even today. Though both the performances appear to have devotional outlook, the undertones in each of them imply the tension between the mass and the King. The people have bifurcated the social reality into two domains: the earthly domain of the King and the heavenly domain of the divine. When the equilibrium of the worldly and the divine gets disturbed in social development, the mass begins to side with the ideal principle of life in the form of the divine so as to restore justice again in life. In other words, if the King turns into a tyrant, the people begin to pray the divine to get rid of such practitioner of power. Shitala Maju or Bijaya Laxmi presents the genuine humanistic plea of the Newars in the form of spiritual mode of resistance in the Valley. In fact, Newar hymns become a space in which the heavenly and the earthly power centers come together into negotiation through the spiritual practice of the people.

Anonymously written as a ballad in the nineteenth century, "Shitala Maju" responds to the historical exodus of Newar children from the Kathmandu Valley during the pandemic of small pox in the early decades of the century. Susan Heydon states that "On 20 November 1816 King Girvana Yuddha Bikram Shah of Nepal died of smallpox" and the palace believed that the Goddess Shitala caused the death. Rana Bahadur Shah had to face multiple attacks of the outbreak of the smallpox virus during his rule, resulting in a very critical situation in the Valley. In order to protect the Prince from transmission of the virus, the King issued a decree to drive away all the infected children from the Valley. Prem Heera Tuladhar perceives:

All the parents of the smallpox affected newly born who were now banished suffered a lot and because of the King's loss of faith towards his fellow citizens, one of the writers then wrote a song on Sitala Maaju in his deep frustration. The same song is now read as a ballad. ... all the Newars during the period of Rana Bahadur suffered a lot and because people had to leave 
everything behind and head into the dark forests outside of the Valley, Sitala Maaju's poem shows the same. (44)

The hymn presents the suffering of the parents of the infected setting out on a journey to the other side of the Tamakoshi River, now in Dolakha. The people develop a type of association with the more rational ideal space of the divine in search for a just order in society. The stoic mass seeks for the Goddess Shitala's favor in the state where the King does not listen to their woes or see their plight in the pandemic. The hymn sings the narrative description of the people, lamenting for the children expunged from the Valley. It describes the historical event in which the people had to undergo huge amount of suffering.

The description of geographically diverse landscape intensifies the pain, resulting from the orders of the King. The path, the climate, the virus, and the polity -all attack the common mass and drive them away from their home. The music and the words arouse pity as the ballad traces the route of the people driven away from Kathmandu: Bhaktpaur, Banepa, Palanchwok, Dolalghat, Dolakha, and finally Tamakoshi. In each stop, they pay their due homage to the deity there: Taleju in Bhaktapur, Chandeshwori in Banepa, Bhagwati in Palanchwok, Bhimsen in Dolakha, and finally Mahadev in Tamakoshi. The song presents the situation thus:

Having left Khopadesa, they stayed the night at Banepa to visit Candesvari shrine.

Having left Banepa, they stayed the night at Palamcok to visit the shrine of Bhagavati.

Having left Palamcok, they stayed the night at Dolaght to visit the shrine of Bhimasena.

Having left Dolaght, they stayed the night near the river Tama.

But they had yet to cross the river Tama.

Having left Dolakhadesa, they arrived on the far bank of the river Tama to visit the shrine of Mahdeva. (6-10)

The torture on the parents of the victims of smallpox puts them in a very complex situation where they are forced to undergo multiple layers of sufferings: first of all, the King has lost the sense of justice and social welfare; secondly, the geography they have to cross is diverse; and thirdly, the uneven weather further tortures them; and finally, the woes of the pandemic almost paralyzes them. The atrocities of the state do not stop there: the army men use nettle to drive the parents away. By intensely exposing the minute details of the torture, the hymn calls for the favour of the divine.

The loss of sense of social welfare, and the rise of concerns for personal, familial safety only expose the most ruthless picture of the rulers in 
any polity. The infection of the virus spread rapidly in the Valley, resulting in a massive number of casualties. The King did not allow the infected children to remain insides the four passes of the Valley, forcing them into exile from their houses. The dead children got no burial ground: the soldiers prohibited the people to cremate their children in any place. Without any means to tackle with the fate imposed on the helpless people, they finally threw the dead body of their children into the Tamakoshi. The hymn pictures it in the following words:

We could not burn the dead child or bury it in a pit. Behold, oh Goddess, the piteous state of your people!

Half of the child's body being seized by his mother, half of the child's body being seized by his father, the parents threw it down into the river Tama.

Since the King had no dharma, he made the parents abandon their smallpox-afflicted children. They had to cross the river Tama.

The people suffered much, when Rana Bahadur was King of Nepal. (16-19)

The people at the bottom of the society respond to the political power in a very critical tone through their words addressed to the Goddess. Analyzing the same situation, Tuladhar reports:

The children walking into the streets died unexpectedly, and the unhappy part is, because the dead body of the child is not even burnt to give it the final death and cannot even be cremated, its half body is held by its father, half by its mother and is thrown away in the holy river of Tamakoshi. (45)

The failure of familial obligation on the part of the parents results from the whimsical attitude of the rulers. The unjust polity provided the people with the worst experience of living in an organized society: the people expected nothing from the King now. They resisted the King and his order by invoking the Goddess, for they believed they held special relationship with the mother Goddess, Shitala.

Rana Bahadur Shah's rule was a terrific political experience to his family members like his people as well. Yet another historical ballad, "Bijaya Laxmi" tells the story of Rana Bahadur Shah's banished wife, Rajrajeshwori. It presents her like the mother to the Prince Girvana Yuddha. Also called Bijaya Laxmi, she stayed in Helambu until she received the news of the death of the whimsical King, Rana Bahadur. This ballad describes the queen in the most humane posture as the anonymous poet pictures her thus: 
Queen Bijayalaksmi was brought from outside. She was living on Mount Helamgu.

When she looked upwards, there were mountains. When she looked down there were waters. The waters were roaring hunuhunu.

She had to drink water from an earthen vessel, to eat her little food from a bowl made of leaves: she has learned the news concerning her husband.

The citizens felt pity. They had erected a dharmashala. The Queen dwelled there at ease.

Having lived free from care, when she heard the news concerning her husband, she announced, "I must commit sati." (1-4)

Of three queens to Rana Bahadur Shah, Bijaya Laxmi was away from the Valley after he married Kantawati as the third one (Shrestha n.pag.). The queen appears in the image of the mother who is attached to the people.

The people show their sympathy to her because she has undergone the exploitation and suffering like the mass at the reign of the King.

The ballad pictures the most brutal picture of the immolation of sati in which Bijaya Laxmi prepares herself ready to commit self - immolation at the pyre of her deceased husband. The queen rises herself in the form of the Goddess, full of compassion for suffering subjects: she thinks of her people, whereby ruling the hearts of the mass. She appears as the most compassionate devi when the poet describes her and her words thus:

"Haya, King! Haya, my son! Do not cause trouble to your subjects! May you be able to strengthen your kindom!"

Queen Bijaya Laksmi mounted the wooden pyre. On her lips the

Queen took the name of Rama.

Bhimsen Thapa was Kaji, Bhimsen Thapa was Prime Minister at that time. The Queen had to die a premature death.

The Queen died. Everyone present shed tears from his eyes. (20-23)

Bhimsen Thapa could have stopped the sati which the ballad implies in the word "premature." The poet expects to see the Prime Minister intervene into the scene of self-immolation; however, the tradition gnaws up her body. On the other hand, the ballad makes no mention of his role in the queen's decision. Still, the people are angry at the state institutions that allow such 
practice. The relationship between the state and the people gets disturbed once more in the ballad when everybody sheds tears at the irrational devotion and lack of the intervention of the political will to save the queen.

Both the hymns practiced even today in the Newar settlements make a case of spiritual resistance from the people at the bottom of the society. The powerless people tend to employ spirituality as a means of critiquing the larger social structures that force people to undergo huge amount of suffering. After losing his faith on the Goddess, Rana Bahadur is said to have attacked the shrines of Shitala (Shrestha n.pag.) Shrestha further states that the King lost both the Prince and his beloved queen Kantiwati of small pox (n.pag.). Against the nature of the balladic performance, "Shitala Maju" sharply critiques the inhuman nature of the ruler. Tuladhar also argues:

Had it been other ballads, the King would have been praised; still, this hymn presents the inhumane nature of the King. All the small pox infected newly born were ordered to be thrown away into the Tamakoshi and we can tell how this ballad was written presenting the unendurable sentiments of those parents. (46)

The stoic travel of the people during the pandemic turns into the most powerful and telling story of their time for the people to see the ways the Kings acted in the past. The key concern of the polity as social welfare was completely annihilated from the exercise of the power of the state. In "Bijaya Laxmi," the state remains completely silent in the matters of the traditional practice. Thus, the people are forced to lose the most compassionate heart of the state who is worried about the welfare of the people all the time.

Both the ballads telescope the uneven political ambition seeking for the justification of the acts of the rulers. Amid the imbalance in the social configuration resulting from the worldly authority, the mass gathers before the divine so as to oppose the ruthless power-structure imposing irrational dictations in the most critical of the times in their life. The Newars of the Kathmandu Valley make use of the spirituality to invoke the divine authority in an attempt to resist the worldly authority of the ruler: Rana Bahadur Shah. Clad in the devotional beats and form, the hymns imbed the contrast between the quest of the rulers on the one hand, and the quest of the people and the divinity on the other. In fact, the hymns grasp the people's will as the divine to imply both the people and their protest in quest of their rightful place in society.

At the micro level, overt and covert forms of resistance occur as per the choice of the people. When the absolute form of power begins to rule the people with the objective of complete subjugation, the people do not and 
cannot protest directly: the threat of power curtails their freedom of expression. In an unjust state, people take to spiritual means to express themselves and their visions for a welfare state. The Newars of the Kathmandu Valley have used the hymns as an instrument of critiquing the power, authority, and social practices by evoking the higher order of the God/Goddess. In addition, the earthly queen, Bijaya Laxmi is also presented in the most humane form in order to evoke the spirit of the deity in her, for the poet wants to arouse the people to develop their perceptions in the dictations of traditions in the mind of the people in the palace. The concerns of the queen at the pyre win the heart of the mass, thereby placing herself as the one from the mass. She has walked among them, taken rest in their places, danced with them, and known their hearts. Bijaya Laxmi and Shilala Maju turn into powerful symbols of human aspiration in the earthly and the divine form respectively in that they complement each other in quest of balance between the top and the bottom in the power structure of the society. The form of resistance employed by the people to oppose the state authority implies that spirituality becomes a political weapon to attack the irrational rule and unjust decisions as well.

The Newar imagination weaves together both the spiritual and the political in their hymns in search of a place of equilibrium in power structure. In breach of the balance, the bottom invents a new mode of expressing its voice of dissent, whereby paving way for protest. Even the most powerful regimes have undergone the most critical hours in history because they fail to see the magnitude of the aspiration of the people at the base of the structure. The collective aspiration obeys the political dictations as long as the focus of the structure lies on social welfare. When the rulers like Rana Bahadur Shah begin to concentrate their energy on the personal safety of their family members only, the mass invents a new mode of expression that sharply goes beyond the expectation of the ruler. Even the most devotional piece of music takes the shape of the most political critical remark, exposing the inhuman spirit and damage from the top. The Newar mindset sings of protest in the form of hymns and promotes the spirit of resistance, bringing together both the political and the spiritual.

\section{Acknowledgements}

My thankfulness goes to Samriddhi Prajapati for her translation of Prem Heera Tuladhar's article from Newari into English. I thank my colleagues Kaminika Nyaichyai, Sundar Shrestha, and Shree Prasad Tyataju at Khwopa College, Dekocha, Bhaktapur, for their wonderful discussion for hours on Shitala Maju. They have inspired me to write this paper. 


\section{Works Cited}

"Bijaya Laxmi."Songs of Nepal: An Anthology of Nevar Folksongs and Hymns, edited by Siegfried Lienhard, Center for Asian and Pacific Studies, 1974, pp. 98-99.

Heydon, Susan. "Death of the King: The Introduction of Vaccination into Nepal in 1816."Med. His., Vol. 63, No. 1, 2019, pp. 24-43.

Holmes, Peter R. "Spirituality: Some Disciplinary Perspectives."A Sociology of Spirituality, edited by Kieran Flanagan and Peter C. Jupp, Ashgate, 2007, pp. 23-42.

Masse, Kaspar. 'Popular Culture, 'Resistance,' Cultural Radicalism,' and 'Self- Formation'."Resistance: Subjects, Representations, Contexts, edited by Martin Butler, Paul Mecheril, Lea Brenningmeyer, Transcript Verlag, 2017, pp. 45-70.

Owens, Bruce McCoy. "Human Agency and Divine Power: Transforming Images and Recreating God among the Newar."History of Religions, Vol. 34, No. 3, February 1995, pp. 201-240.

Parish, Steven M. "The Sacred Mind: Newar Cultural Representation of Mental Life and the Production of Moral Consciousness."Ethos, Vol. 19, No. 3, September 1991, pp. 313-351.

"Shitala Maju."Songs of Nepal: An Anthology of Nevar Folksongs and Hymns, edited by Siegfried Lienhard, Center for Asian and Pacific Studies, 1974, pp. 99-101.

Shrestha, Sudip. "Kathmanduka Newarle Thulo Moolya Chukaeko 223 Varsh Pahileko Mahamari" [223-Year Old Pandemic in which Kathmandu Newars Paid a Huge Price]. Setopati, 15 April 2020, https://www.setopati.com/social/203975?fb_comment_id=374389 $1305686005 \_3744095752332227$. Accessed 31 October 2020.

Tuladhar, Prem Heera. "Shitala Majuya Bare Chhu Kha" [A Piece of Writing on Shiltala Maju]. Sharada, Kartik 2064 B.S. pp. 43-46.

Widdess, Richard. "Text, Orality, and Performance in Newar Devotional Music."Tellings and Tales: Music, Literature and Performance in North India, edited by Francesca Orsini and Katherine Butler Schofield. Open Book Publishers, 2015, pp. 231-245. 